\title{
Critical remarks on 'Religion in the public sphere' - Habermas between Kant and Kierkegaard
}

\section{Roe Fremstedal}

This article provides a critical assessment of Habermas's recent work on religion and the role of religion in the public sphere by comparing it to Kant's philosophy of religion on the one hand and that of Kierkegaard on the other. It is argued that although Habermas is in many ways a Kantian, he diverges from Kant when it comes to religion, by taking a position which comes closer to the Kierkegaardian view that religiousness belongs to private faith rather than philosophy. This has implications not just for the conception of religion but also for the very roles of communication, validity, rationality, and philosophy.

Keywords: rationality, religion, truth claims, universality, validity claims

\section{The understanding of others as an external criterion for truth - Kant}

According to Kant, the touchstone for assessing the objectivity of subjective judgements (claims about something being true) is whether others agree (AA 7: 219, 128; cf. KdrV A820f/B848f). Kant says that we cannot do without the understanding of others because such an understanding is an external criterion for truth. Without this criterion, we could not test the correctness of our own judgements, and hence we would be at the mercy of mistakes (AA 7: 128; cf. 2: 334, 349). This criterion means that the rational validity of judgements depends on it being possible to communicate them universally (Wood 1970: 202; cf. AA 6: 108f). This also provides the background for Kant's defence of freedom of expression and freedom to publicise. It should be noted, however, that since the German mitteilen can mean 
to 'share with others', Kant may be read as demanding universal 'shareability' rather than 'communicability' (Kulenkampff 1978: $191 \mathrm{n} 15$ ).

Kant used this account of rational validity to criticise forms of religiousness that cannot be shared or communicated universally, in a theme that runs through Kant's writings from the 1760s to the late 1790s. In 1764, Kant wrote that 'the fanatic (visionary, enthusiast [Schwärmer])' is 'properly a deranged person with presumably immediate inspiration and a great familiarity with the powers [Mächten] of the heavens. Human nature knows no more dangerous illusion [Blendwerk]' (AA 2: 267). In Religion within the Bounds of Bare Reason (1793-1794), Kant says: 'To want to perceive heavenly influences is a kind of madness in which $[\ldots]$ there $[\ldots]$ always remains a self-deception' (AA 6: 174, cf. 19: 644). In the prolonging of this, Kant depicts '[e]nthusiastic religious delusion [schwärmerische Religionswahn]' or the notion of unmediated presence of God, as 'the moral death of reason' (AA 6: 175). In the Lectures on Ethics from 1793, Kant is reported to have described the claim to an immediate intercourse, fellowship and social connection [Umgang, Gemeinschaft und gesellschaftlichen Verbindung] with God' as 'Arrogance (an apotheosis of humanity in our own person)' (AA 27: 726). In Anthropology from a Pragmatic Point of View (1798), Kant writes that it is madness to believe that one is chosen and that one interacts with or is given an extraordinary revelation by - a higher being. According to Kant, the characteristic feature of madness is that one isolates oneself. He describes the person who does not consider it necessary to test his judgement against the understanding of others as a being a logical egoist (AA 7: $219,128)$. Kant stressed that 'its constitution as universally communicable [allgemein mittheilbar]' constitutes 'the essential characteristic of the religion which ought to bind every human being' (AA 6: 155). The upshot of Kant's analysis is that, like other judgements that claim to be rationally and universally valid, religious judgements must be capable of being universally shared or communicated. It should be noted that this does not necessarily amount to religious judgements being redeemed discursively. For instance, religious narratives may be communicable without being argumentative. However, arguments must also be communicable or shareable. Onora O’Neill explains Kant's account as follows:

The minimal, modal requirement that reasons be followable by others, without being derivative from other standards, is Kant's entire account of the authority of reason. Yet mere nonderivative lawlikeness has considerable implications for the organization of thought and action: in the domain of theory it amounts to the demand that reasons be intelligible to others; in the domain of action it amounts to the requirement that reasons for action be ones that others too could follow. (O'Neill 1997: 276) 


\section{Habermas's conception of religion}

In 'Faith and Knowledge', Habermas's Peace Prize address delivered at St. Paulskirche in Frankfurt a month after the 9/11 attacks on the USA, Habermas describes the boundaries between secular and religious reasons as fluid (flieend), making it clear that he believes in the 'continued existence of religious communities within a continually secularizing society' (Habermas 2001; 2003: 109). Habermas suggests that one must engage with religion without losing critical distance to it and talks about 'the reasonable attitude of keeping one's distance from religion without closing one's mind to the perspective it offers' (Habermas 2003: 113). In this respect, Th.M. Schmidt comments:

Habermas now fully advocates a permanent coexistence of religious and secular convictions. [...] Habermas now increasingly advocates a fallibilitst attitude on the part of the post-metaphysical thinking: finite secular reason subjects itself to the express proviso that it might err. [...] fallibilism also applies to the secular citizen, who must also accept the possibility that the religious conviction might also be true. (Schmidt 2005: 83)

Habermas suggests that religion can be conceived of as a source of truth that, since it has not been exhausted, provides an important resource for modern society. Religion seems to be a resource either because the truths of religion to some are extent capable of being translated into discursive arguments or because religion does not rely on publicly reason-giving. The latter conceives of religion as an alternative source of truth, a source that transcends discursive rationality and publicly available criteria.

In 'Religion in the Public Sphere' (2006), Habermas describes his position as follows:

In short, post-metaphysical thought is prepared to learn from religion, but remains agnostic in the process. It insists on the difference between the certainties of faith, on the one hand, and validity claims that can be publicly criticized on the other; but it refrains from the rationalist presumption that it can itself decide what part of the religious doctrines is rational and what part irrational. [...] At best, philosophy circles the opaque core of religious experience when reflecting on the intrinsic meaning of faith. This core must remain so abysmally alien to discursive thought as does the core of aesthetic experience, which can likewise only be circled but not penetrated by philosophical reflection. (Habermas 2006: 17; cf. 2005: 251)

Habermas's account suggests that that there are two sides to religion: one that concerns public criticisable validity claims and one that does not. These two aspects or parts seem to reflect knowledge and faith, respectively. 


\section{Does Habermas's view hold for all types of religion?}

Whereas a rationalist would be inclined to view religion that does not concern publicly criticisable validity claims as false religion, Habermas would not go that far. Quite the contrary, Habermas sees the core of religion as not concerning validity claims that can be publicly criticised (cf. Habermas 2006: 17, 9). However, it is not clear why Habermas conceives of religion in this particular way. It seems that the opaque core that evades discursive deliberation can refer to: (1) the Absolute, Infinite or Unconditioned as such or God understood as hidden; (2) the mystery of divine grace in supernatural religion, as found for instance in Kant's rational faith (AA 27: 309f; 6: 174); and (3) revelation. The first may be found in many, if not most forms, of religion (e.g. Plato's conception of the Good as beyond being and non-being), whereas the latter two are typically found in Judaism, Christianity or Islam.

A clear example of religion transcending public criticisable validity claims is the belief in a special divine authority that transcends deliberation exemplified by Kierkegaard's conception of revealed faith (SKS10: 199; SV13: 181; Pap. VII2, B235: 24, 65, 146ff). Interestingly, in an article that seems to anticipate this recent position, Habermas distinguishes sharply between argumentative discourse and the event of revelation:

Philosophy cannot appropriate what is talked about in religious discourse as religi-
ous experiences [Erfahrungen]. These experiences could only be added to the fund
of philosophy's resources, recognized as philosophy's own basis of experience, if phi-
losophy identifies these experiences using a description that is no longer borrowed
from the language of a specific religious tradition, but from the universe of argumen-
tative discourse that is uncoupled from the event of revelation. (Habermas 2002: 74f)

The way Habermas slides from discussing religious experience to the event of revelation may suggest that rather than being concerned with religious experience more generally, he is concerned with the experience of revelation in particular. Interestingly, there is a tendency in Habermas towards collapsing religion as such into religion based on a 'revealed Word' (cf. Habermas 2002: 164):

\footnotetext{
By dint of their possibly even rationally defended reference to the dogmatic authority of an inviolable [unantastbaren] core of infallible relevatory truths, religiously rooted existential convictions evade that kind of unreserved discursive deliberation [vorbehaltloser diskursiver Erörtung] to which other ethical orientations and world views, i.e. secular 'concepts of the good' [weltliche «Konzeptionen des Guten»] expose themselves. (Habermas2006: 9; 2005: 135)
}

Habermas (2005: 251f) seemingly understands the opaque core as implying transcendence from without, something which suggests a revelation. Indeed, it has been suggested that rather than dealing with religion in gene- 
ral, Habermas focuses on the three main monotheistic religions in 'Religion in the Public Sphere' (Skirbekk 2005: 27). So far, the claims made in Habermas's recent works suggest that there cannot be any public available criteria when it comes to revealed faith. If this is correct, Habermas's approach is in line with the Kierkegaardian idea that, somehow, revealed faith relies on private criteria without necessarily precluding the possibility of a universal religion. ${ }^{1}$ From this understanding, the conception of religion in Kierkegaard (cf. Evans 2006b: 255) and Habermas is fundamentally at odds with traditional (e.g. Thomist) views that a revelation would be accompanied by wonders or miracles, the latter serving as public - although not repeatable - criteria.

Insofar as Habermas's thesis about the opaque core of religion refers to revealed faith, it relies on a somewhat Kierkegaardian conception of the revealed as something opaque rather than transparent. Kierkegaard says that the Christian revelation is opaque (dunkel) even to the believer (Pap. IV C1: 355, 368; cf. Lübcke 2006: 411). Against this, Kierkegaard's critics might say that a revelation that is opaque is not a revelation. As the term itself suggests, revelation - re-veilatio - means to remove the veil so that we see more clearly. If Kierkegaard claims that the revelation is as opaque to the believer as to the non-believer, then his Christian solution can hardly be a solution at all (cf. Lübcke 2006). This depiction of Christian faith, although originally presented by a Christian thinker, has often been taken to provide good reasons why one should not be a Christian. Indubitably, this is the effect that Kierkegaard has had on much of 20th century thought, especially existentialism. Elsewhere, however, Kierkegaard presupposes that revealed faith can solve problems inherent in the pre-religious life (cf. Lübcke 2006: 411f; Knappe 2004: 125; Kosch 2006: 7, 139, 182). For example, he claims that neighbourly love solves problems inherent in human love (Evans 2006a: 149f). I take this to mean that the revelation must be less opaque to the believer than to the non-believer. Needless to say, total transparency is never reached in this world.

\section{The natural dialectic of reason}

In some passages, Habermas simply aligns reason with public reason-giving and says that religious discourse should be interpreted by 'virtue of its argumentation alone' (Habermas 2002: 77). Elsewhere, however, Habermas does not equate reason with reason-giving or discursive deliberation. Taking his lead from Kant, Habermas (2005: 27-39, cf. 251f) conceives of reason not merely as argumentative but also as transcending reason-giving. Importantly, Kant's solution to the antinomies of reason in the first Critique can be seen as leaving room for faith that transcends public reason-giving. 
On Kant's account, reason is inevitably driven to exceed the limits of the understanding because reason seeks wholeness and something unconditioned that explains everything without itself requiring any explanation. The conflict between reason's absolute demand for meaning and the limitations of finite understanding can be interpreted as corresponding to, and finding its expression in, religiousness. According to Kant, practical reason seeks the unconditioned totality of the object of practical reason under the name of the highest good (AA 5: 108). The highest good, the most central concept in Kant's philosophy of religion, is elsewhere characterized as the kingdom of God, the ethical commonwealth and happiness conditioned by virtue (AA 5:127ff, 113-115; 6:97ff).

Thus conceived, the room that Kant found for religion within the bounds (Grenzen) of bare reason goes beyond what can be justified discursively (cf. Trautsch 2004: 194). Interestingly, Kant's project of enclosing religion within the bounds of reason (cf. AA 4:352; Palmquist 1992: 132) appears to coincide with Habermas's encircling of the opaque core of religion. If the opaque core of religion corresponds to reason's striving for totality and the unconditioned, this means that it is possible after all that Habermas's view can hold for all types of religion. Additionally, the opaque core could also refer to that which transcends reason altogether, e.g. divine grace (2) and revelation (3). Thus, the opaque core could include what transcends or even breaks with reason, morality, 'shareability', and communicability. I will return to this point later.

Although Kierkegaard may have been influenced by Kant's analysis of the dialectic of reason, he makes a slightly different use of it than Kant (cf. Evans 1999: 222ff). Kierkegaard (the pseudonym Climacus) claims that although dialectics cannot reach the Absolute as such, they can point towards it. He says that the highest passion of the understanding lies in transcending itself (by transcending its limits) and becoming faith. He is careful to point out, however, that worship of the absolute does not belong to dialectics (SKS 7:444f; 4:243f, 252f; SV10:169f; 6: 38ff, 47f). Whereas Kant endorses religiousness in the name of practical philosophy, Kierkegaard holds that philosophy cannot endorse religious faith, in particular not Christian faith. Habermas appears to be more of a Kierkegaardian than a Kantian at this point since he sees religious faith as something which belongs to private faith rather than philosophy.

Even if Kant concedes that the moral faith of practical reason transcends reason-giving, he nevertheless insists that this faith is universally communicable or shareable and that it ought to bind every human being. Habermas, on the other hand, may concede that something non-argumentative, such as religious narratives, can be communicated, but he does not accept that it is binding on us. Kant, however, claims that the dialectic of reason leads to the antinomy of practical reason (AA 5: 107-148), an antinomy 
which can only be solved by moral faith. He suggests we are led into a labyrinth and that moral faith represents the key to escape (cf. AA 5:107). This provides the background for Kant's defence of moral faith.

It should be noted that since moral faith transcends argumentation, it is misleading to speak of Kant's moral argument (or moral proof) for the existence of God and immortality. The moral 'argument' is based on the possibility of realising the highest good, thereby avoiding the problem that the virtuous are unhappy (cf. Wood 1970, especially Ch. 1). Importantly, in Kant the realisation of the highest good is seen as the solution to the fundamental problem of bridging freedom and nature or realising the Moral Law in this world. It should be noted that although Habermas discusses Kant's philosophy of religion at length in Chapter 8 of his book Zwischen Naturalismus und Religion (2005) he never really addresses the moral argument. Although he concedes that communicative reason cannot become reconciled with its finite conditions merely by the force of arguments, Habermas insists that philosophy (as such) should not defend faith. This is at odds with both Kant's moral religion and other types of philosophical religion, for instance Platonic and Buddhist types. ${ }^{2}$

\section{Translation of religious thinking}

On the one hand, Habermas (2006: 10, cf. 11, 19,23) conceives of translation as a modernization and a transformation from religious reasons to secular reasons, while on the other hand he conceives of it as a transformation into a 'generally accessible language. Of encounters with religious traditions, he writes:

\footnotetext{
Philosophy [...] receives innovative stimulation if it succeeds in liberating the cognitive substance from its dogmatic encapsulation in the melting pot of rational discourse. Kant and Hegel are the best examples of this. And further evidence provides the encounter of prominent philosophers of the 20th century with a religious thinker such as Kierkegaard, who thinks in a post-metaphysical, but not a post-Christian vein. (Habermas 2006: 17)
}

The suggestion that Kant and Hegel are the best examples of translation makes it somewhat unclear what translation amounts to. Within his critical philosophy, Kant reinterpreted and reconstructed religious writings, focusing on the concept of the highest good (of the kingdom of God) and the moral principle in the Gospels (AA 5: 127f, 86; cf. 471f). Kant goes as far as saying that he wants to demonstrate how the possible unity of Christianity and the purest practical reason are to be understood (AA 11:429, cf. 10: 180, 7:44). Although he sought to formulate what is translated in a 'generally accessible language', Kant still described it as religious and even Christian. 
Rather than representing a transformation from religious reasons to secular reasons (as Habermas appears to assume), Kant's type of translation entails a transformation from historical (statutory) faith to moral (rational) faith something which amounts to universalization (i.e. eliminating singular terms in maxims). Kant postulates not merely the (possible) existence of God and immortality, but the existence of divine grace within supernatural religion (AA 27:310; 6:138f, 174; Wood 1970: 232ff; Marina 1997). If this is what Kant's translation of religion amounts to, Habermas appears to be unable to accept it.

When discussing political theory, Habermas (2006) aligns secular reasons with a generally accessible language. This gives meaning, since it is only that which is secular that can be counted as generally accessible and justifiable in the modern political context. Also, Habermas conceives of the translated result as argumentative or reason-giving. This means that although narratives can be formulated in a general accessible language, mere narratives would not suffice for Habermas. Also, the room that Kant finds for religion in the dialectic of reason must be excluded from the domain of political decision insofar as it transcends reason-giving and secularity. Although Habermas's narrow conception of translation does work in the political context, translation should be conceived of in terms of accessibility rather than secularity outside this context. The philosophy of religion needs a wider conception of translation that does not exclude what is neither argumentative nor secular as long as the translated result is compatible with the Moral Law and universally communicable or shareable.

When Habermas depicts translation as transformation into secular reasons this can leave the impression that what is translated is not religious any more. However, Habermas (2006: 19) explicitly states that 'Only the participants and their religious organizations can resolve the question of whether 'modernized' [i.e. translated] faith is still the 'true' faith.' This leaves the possibility that insofar as religious reasons can be translated, they may consist of, for example, ethics rather than religion. Actually, Habermas was inclined to believe this earlier (Trautsch 2004: 190). Also, the prospect of religion being completely translated suggests that religion could end up being reduced to something else (e.g. resources for meaning and identity).

Although Habermas may not have been perfectly clear about this earlier, he is clearer in his post 9/11 publications, starting with 'Faith and Knowledge', conceding that the realm of faith as such has some independence insofar as it does not contradict reason (Trautsch 2004: 195). If this Kantian reading is correct, Habermas denies independence to religion insofar as it contradicts reason. Kant's approach to religion leaves room for faith as long as it can be shared or communicated and as long as it is compatible with the Moral Law, thereby excluding Abraham's sacrifice of Isaac (AA 7: 63n; 6: 87, 187). Nevertheless, these restrictions do not preclude religion transcending 
reason, for instance by including belief in divine grace (2). Furthermore, although objectively revealed faith (3) is hardly communicable it is still possible that it can be shared and that it can be compatible with reason.

This raises the question of how much can be included in reason. Is it potentially everything that can be shared or communicated and does not contradict the Moral Law, or is it merely that which can be redeemed discursively and that which corresponds to the dialectic of reason? Although, Habermas appears to choose a broadly Kantian solution, Habermas's fallibilism, as well as his description of the boundaries between secular and religious reasons as fluid (flieend), makes it hard to draw the line between religion compatible with reason and religion incompatible with reason. This suggests that translation of religious language and engagement with religion is risky. Kierkegaard is typically seen as a paradigmatic example of a thinker who wholeheartedly embraced this risk and refused to articulate criteria that can exclude irrational or immoral faith. Notwithstanding this reputation, even Kierkegaard attempts to develop criteria for disclosing false revelations in the Book on Adler (Evans 2006b: Ch. 14).

\section{What stands in need of translation?}

Kant claims that historical (statutory or revealed) faith needs translation in order to be compatible with the Moral Law and to become part of philosophy. Insofar as the thesis about the opaque core of religion refers to revealed faith, Habermas would have to agree with Kant that revealed faith stands in need of translation. However, Habermas clearly states that it is religious reasons more generally that stand in need of translation. This claim has been criticised on the grounds that religion in itself is not the special case that Habermas wants it to be, since any comprehensive worldview or metaphysical argument stands in need of translation as much as religion does (Myskja 2008).

Although Habermas does not say so himself, his views on translation seem to be essentially in line with the following approach: Kant suggests that the content of religion can be correct or true even if one believes that one first became aware of it through a revelation. Kant would seem to allow for religion to be seen as revealed when considered subjectively if it is natural (rational) when considered objectively (AA 6:155f, cf. 11:321). In this context, to consider objectively concerns why I believe (i.e. my reasons), whereas the subjective can be interpreted as how I come to know this religion (Byrne 2007: 168f, 159ff, 154f; cf. Palmquist 1992: 137). This line of interpretation would also be in line with Kant's general claim that historical faith can be useful insofar as it leads to rational (moral) faith. Kant's com- 
ment on the title of Religion within the Bounds of Mere Reason should also be noted in this context:

My purpose in formulating this title was to prevent a misinterpretation to the effect that the treatise deals with religion from mere reason (without revelation). That would be claiming too much, since reason's teachings could still come from men who are supernaturally inspired. The title indicates that I intended, rather, to set forth as a coherent whole everything in the Bible - the text of the religion believed to be revealed - that can also be recognized by mere reason. (AA 7: 6n)

Kant's point about translating religion can also be extended to cover translation of metaphysical views and comprehensive worldviews, since it is equally possible to have good reasons if one first became aware of them by subscribing to a comprehensive worldview or a metaphysical doctrine.

\section{To what extent is translation possible?}

Regarding comprehensive worldviews and metaphysical doctrines more generally, it seems that translation is possible to the extent that these worldviews and doctrines can be rationally reconstructed. It remains an open question of a largely empirical nature as to how far translation can or will succeed. However, if we are dealing with revealed faith, the question of whether translation is possible is not merely an empirical one because it depends on how one conceives the relation between revealed faith and rational (natural) religion. This is a conceptual problem rather than an empirical problem. Translation is obviously possible insofar as religion is revealed when considered subjectively and it is natural (rational) when considered objectively. However, translation must be impossible to the extent that (objectively) revealed faith is against reason or over reason (reason taken in a wide sense that includes dialectics).Further, of course, insofar as language is not communicable, it is not translatable either.

If translation of religious language is essentially impossible, Habermas appears to admit that religious language is valid as such. This is suggested by his claim that the rhetorical power of religious speech (rede) is valid as long as we have not found a more convincing language for the experiences (Erfahrungen) and innovations that are contained in it (Habermas 1988: 34). A more convincing language seems to refer to secular reasons or a generally accessible language. Habermas (2002: 163) has stated that he does not know whether religion could be completely translated or whether it will forever resist such efforts. However, his 2005 position, in particular the thesis of the opaque core of religion, commits him to the view that religion cannot be completely translated into reason-giving. Still, Habermas believes it is possible to translate religious language: 
Whereas citizens of faith may make public contributions in their own religious language only subject to the provision that these get translated, the secular citizens must open their minds to the possible truth content of those presentations and enter into dialogues from which religious reason then might well emerge in the transformed guise of general accessible arguments. (Habermas 2006: 11)

In Habermas's view, religious traditions have a special power to articulate ethical intuitions, and he warns that excluding religion from the public sphere could mean cutting oneself off from key resources for the creation of meaning and identity (Habermas 2005: 236; 2006: 10). Habermas's examples are:

Universalistic egalitarianism, from which sprang the ideals of freedom and a collective life in solidarity, the autonomous conduct of life and emancipation, the individual morality of conscience, human rights and democracy, is the direct legacy of the Judaic ethic of justice and the Christian ethic of love. This legacy, substantially unchanged, has been the object of a continual critical reappropriation and reinterpretation. Up to this very day there is no alternative to it. (Habermas 2002: 149, cf. $160,132 f, 137)$

Thus, the resources religion provides for the creation of meaning (and identity) are not yet exhausted (unabgegoltenen) (Habermas 2002: 71, 162). This would be in line with an approach to religion that values it insofar as it solves pre-religious problems (e.g. problems related to meaning and identity). According to Habermas's account, religion has the potential for enriching public deliberation. Excluding religion from discussion - as is the case with reducing the pool of arguments more generally - means running the risk of overlooking arguments. This is a concern common to Habermas and various proponents of deliberative democracy as well as to Kierkegaard (the pseudonym de silentio) (SKS4: 177, cf. 180f, 201; SV5: 80, cf. 83, 102).

\section{A note about the interpretation of Kant's philosophy of religion}

In discussing how religions traditions can be reinterpreted and justified philosophically, Habermas claims that Kant's philosophy of religion deserves our interest because it shows that practical reason can learn from the power of articulation that we find in the world religions (Habermas 2005: 236). On this account, religion can contain truths (for instance, about human dignity, forgiveness, and the kingdom of God) which can be reinterpreted and justified philosophically.

In Religion (1793-1794) and Conflict of the Faculties (1798), Kant attempted to distinguish between two main types of religion by drawing a distinction between moral religion on the one hand and historical faith, 
revealed faith, church service, and statutory religion on the other (AA 6:102-104, 115, 119ff, 129ff, 165-167, 153f, 176ff; AA 7: 50). In contradistinction to the latter, moral religion holds that no special duties towards God exist in addition to duties towards human beings. Put differently, while moral religion is based upon universalistic ethics, church service implies (non-universalisable) special duties towards God and a special relationship with God that is not available to all. Thus, church service or statutory religion implies some kind of ethical particularism (Hare 2002: 152f, 218n).

Kant tends to see revealed faith as being based on something empirical (a revelation, holy book, or historical faith) rather than on the Moral Law. For Kant this means that instead of being based on our common reason, revealed faith is only available to some. Furthermore, since it is not available to everyone, it cannot be valid for all, Kant claims (cf. AA 6: 104, 115, 155, $179,168,185)$. Thus, Kant denies that a revealed religion can be a universal religion (AA 9: 477). This is a controversial claim to say the least (cf. Hare 2002: 66). Nevertheless, in some passages Kant seems to be saying that (presumably objectively) revealed faith can be valid for some, thereby suggesting that it can be valid for everyone who is in the special situation of having received a revelation. This 'local' validity can be interpreted as saying that revelation can be useful or even necessary for certain people and certain eras, probably on the grounds that it can lead to moral faith (cf. AA 7:37f, 28:1119-1122; Hare 2002: 44).

Habermas says Kant would not accept, as Hegel would, that historical faith is part of the genealogy (Entstehungszusammenhang) of reason itself (Habermas 2005: 236f). Nevertheless, Kant stresses that historical faith contributes to the development of moral faith and practical reason. Clearly, Habermas interprets Kant as wanting to do away with revealed faith that cannot be translated into moral faith (Habermas 2005: Ch. 8, especially 231, 237f; cf. 2006: 17; 2001). Of Kant, Habermas writes: 'He draws a sharp line between the moral belief of rational religion and the positive belief in revealed truths' (Habermas 2003: 111). Admittedly, there is some evidence for this. In a passage from which Habermas (2003: 111) cites, Kant states: 'The leading-string of holy tradition, with its appendages, its statutes and observances, which in time did good service, become bit by bit dispensable, yea, finally, when a human being enters upon his adolescence, turn into a fetter' (AA 6: 121f). Kant goes on to say, yes, the ecclesiastical faith (in its historical aspect) can eventually be dispensed with (AA 6: 153).

Although Habermas takes Kant to be saying that ecclesiastical faith can be dispensed with today, it is not clear that Kant actually says this. In a difficult but important passage, Kant writes: 'Not that it [statutory or historical faith] «will cease [aufhöre]» (for it might always be useful and necessary, perhaps as a vehicle) but that «it can cease»; whereby it is intended only the 
intrinsic firmness of pure moral faith' (AA 6: 135n). R.L. Louden comments on this passage as follows:

This suggest that human beings will eventually 'see through' the various historical churches, so to speak, and realize that their trappings are merely all-to-human vehicles or conducting agents for truth rather than truth itself. However, we still need these trappings, for our image-dependent nature requires us to hold onto them. Kant exhorts us to 'work diligently even now' for 'the continuous development of the pure religion of reason from its not yet dispensable shell' ([AA] 6:135n), but he also states that the visible forms of historical churches will be dissolved only when 'all earthly life comes to an end' ([AA] 6: 135). [...] In other words, ecclesiastical faith is not to be 'abolished by progress. Rather, it is to come to an understanding of itself as a vehicle for pure religious faith, so better to serve the pure faith which is its essence.' (Louden 2002: 129f, quoting Wood 1970: 196 at the end)

In several passages Kant is not as dismissive of historical faith and revelation as Habermas would have us think (cf. AA 7: 44, 37; AA 6: 135; AA 28: 11191123). Kant is much more ambivalent towards revealed faith than presupposed by Habermas. Indeed, Kant's comments on this issue have led to strong disagreement between commentators about whether historical faith is necessary on Kantian terms. ${ }^{3}$ Although Kant attempts to draw a line between moral religion and revealed faith, the line is not as sharp as Habermas would have us to believe. Kant appears to admit that religious language cannot be translated completely into a rational language. His claim that morality in general is an inexhaustible field (AA 27: 466) can probably be extended to cover moral religion as well.

\section{Methodological atheism and agnosticism}

Habermas (2002: 160) states: '[A] philosophy that oversteps the bounds of methodological atheism loses its philosophical seriousness.' Unfortunately, it is not clear what methodological atheism amounts to. A case in point is provided by 'Transcendence from Within, Transcendence in this World', where Habermas starts by saying that he is going to explain what methodological atheism really means, and ends by quoting J. Glebe-Møller's 'political dogmatic' at length (Habermas 2002: 75-78). The two main points in Glebe-Møller's argument are, as presented by Habermas:

The thought of a personified divine power necessarily involves heteronomy, and this is an idea that goes directly against the modern concept of human autonomy. A political dogmatic in the modern context must therefore be atheistic.

[G] uilt remains in effect. Instead of resigning ourselves to it, however, we must make the consciousness of guilt into something [...] that spurs us to fight against the conditions that have produced the guilt. (Glebe-Møller quoted in Habermas 2002: 77, 78) 
Here, Habermas leaves the impression that he approves of Glebe-Møller's argument, but it is not fully clear that he actually does so. In my view, Habermas would be better off rejecting the former argument since autonomy needs neither to exclude a personified divine power nor divine command ethics. First, autonomy is compatible with a weak form of divine command ethics where divine commands are conceived as being determined by reason. Second, Kantian autonomy is compatible with a personified divine power and divine command ethics. Kant actually tries to make autonomy consistent with seeing our duties as divine commands, describing our duties as being commanded by God. ${ }^{4}$ Additionally, the point about guilt is clearly at odds with Kant's transcendental analysis of evil. According to Kant, evil must take the form that it corrupts the ground (Latin: radix) of all maxims. Kant stresses that this evil is 'not to be extirpated through human forces, for this could happen only through good maxims - something that cannot take place if the subjective supreme ground of all maxims is presupposed to be corrupted' (AA 6: 37, cf. 45). Although Kant stresses that we must try to do our duty with all our power, he is clear that evil and guilt leads to the need for divine grace. If Kant is correct, then Habermas would be better off rejecting the latter argument as well.

Notwithstanding these difficulties, an attempt at an explanation is provided by Austin Harrington, who writes that Habermas's methodological atheism

[...] denotes not a personal avowal of non-belief in the existence of God but only a methodological maxim that, in the practice of their research, social scientists should make no assumption that God exists. Habermas's claim is that as long as this maxim is observed, whatever religious belief and values a social scientist may or may not possess or may or may not have inherited from an educational tradition, these beliefs and values are irrelevant to the objective validity claims of the social scientist's research. (Harrington 2007b: 549f)

If we do concede that it is appropriate for the social scientist or a political philosopher to be a methodological atheist, this does not mean that the same holds for someone concerned with a normative question such as 'What I may hope?' Although the social researcher as a researcher cannot be concerned with God's existence, this does not imply that the same holds for the researcher as a person or even that it holds for an existential philosopher or a philosopher of religion.

I believe we find a very different approach to religion - and especially revealed faith - in Kierkegaard and Wittgenstein. Kierkegaard (Climacus) stresses time and time again that religion is all about taking risks and not being indifferent, claiming that this is one of the most fundamental characteristic of religion altogether. Put in Wittgeinsteinian terms, the religious language game is characterized by risk-taking and the impossibility of being 
indifferent (cf. Fremstedal 2006b). If this is the case, Habermas's approach is simply not appropriate for the subject he wants to study.

Although Habermas favours a rational critique of religion, his methodological atheism might be at odds with this. Harrington comments:

Even venturing to think about whether religion is rationally acceptable is here made subordinate to a prior choice for a methodological strategy [...] Methodological atheism is thus already a suspension of the very idea of the appeal and attraction of investigating religion for its content of truth. In Habermas's recent work, critical evaluation of religious contents is no longer pursued substantially but only indirectly or 'methodologically'. Should not an authentic engagement be open to taking on more risks than this? (Harrington 2007b: 550)

It hardly seems possible to do justice to religion without assessing truth claims. Is it not under the condition that religion concerns how we live our lives that it is rendered meaningful at all? (cf. Fremstedal 2006b: 214ff). As Habermas himself has argued at length in the introduction to The Theory of Communicative Action (1981), there is an internal relation between the question of meaning and the question of validity. Habermas claimed that 'a social-scientist observer cannot understand the meaning of a spoken utterance of action without taking up a normative position on its validity or rationality' (Harrington 2007b: 551; cf. 2007a: 53f.). Yet Habermas diverges from this insight in his analysis of religion. In particular, his methodological atheism is at odds with this thesis. However, Habermas appears to concede this point, saying that that religious and aesthetic experience contests the analysis of the relation between validity and meaning in universal pragmatics.

Rather than describing himself as a methodological atheist, Habermas now appears to describe himself as an agnostic or a sceptic:

The secular counterpart to religious modernization is an agnostic, but non-reductionistic philosophical position. It refrains on the one hand from passing judgements on religious truths while insisting (in a non-polemical fashion) on drawing a strict line between faith and knowledge. It rejects, on the other, a scientistically limited conception of reason and the exclusion of religious doctrines from the genealogy of reason. (Habermas 2006: 16; cf. 2005: 147)

The original German edition starts the second sentence by writing 'Unter agnostischen Prämissen', suggesting that Habermas is relying on agnostic premises. At this point I would like to pose the following question: Is not Habermas's agnosticism a consequence of presupposing that religion belongs to private faith rather than philosophy?

Moreover, there can be little doubt that Habermas's approach to religion has a political and legal character that focuses on political conflict resolution. However, such an approach may not be particularly appropriate for 
investigating more existential questions regarding reason and faith. This concern has been voiced by Austin Harrington:

Could it not be that Habermas transfers too much from the political relation of the religious and the secular to the existential relation to the philosophical and theological? What seems troubling is his appeal to pluralism and tolerance under the democratic state of law as a framework for our understanding of a conflict that might be conceptually more primordial than this. If so, the worry is that the style of his argumentation may be predisposing it to a particular outcome. (Harrington 2007b: 548)

According to Harrington, the 'Conflict of the Faculties' of the mind, as found in the late Kant, is arguably a more primordial kind of conflict than that between different cultures, identities and religions under the democratic state of law.

Of course, being religious (or a religious citizen) does not equate with supporting a state church or being opposed to a secular state. Being convinced of a religious truth is not tantamount to wanting to give this truth a privileged political and legal status. From Kierkegaard's point of view, it is precisely when a person is convinced of a religious truth that that he should be most opposed to it being privileged in a worldly order. For what is truly divine and transcendent cannot be identified with a worldly order without thereby being corrupted (Evans 2006a: 7, 329). C.S. Evans has even claimed that it is difficult to find one religious thinker who is more sensitive than Kierkegaard to the dangers of giving one particular religion a privileged status.

\section{A somewhat one-sided approach}

Habermas (2006: 8) writes: '[T]rue belief is not only a doctrine, believed content, but a source of energy that the person who has a faith taps performatively and thus nurtures his or her entire life.' In this context, Habermas refers to the Augustinian distinction between faith that is believed and the faith by which we believe. Put in Habermasian terms, this is the distinction between the propositional content of faith and the performative act of believing. In Habermas we find a tendency to focus on the former. Kant and Kierkegaard, on the other hand, tend to focus on the performative force of religious faith and hope rather than on the doctrinal content of faith. Thereby, they are more concerned with the moral and existential functions of religiousness than with dogmatics. Habermas, however, is mainly concerned with the 'inviolable core of infallible revelatory truths', 'truth content', semantic potential, cognition and doctrine (Habermas 2006: 4, 8-11, 1317). He tends to view the core of religion as something non-argumentative 
and opaque that has to do with doctrine rather than with being hopeful. As Harrington puts it:

[...] Habermas almost always speaks only of semantic content of religion and almost never of religious forms: almost always of message, rarely of medium. [On Habermas's account,] Religious message offers potential for discursive redemption, but religious form, it seems, is peripheral and inessential. This seems to entirely to leave out of consideration the non-discursive or semi-discursive aspects of religious life, bound up with ritualized action and gesture, music, song, visual representation, and the sensuous space and event of worship. None of these elements play any accountable role in the programme [of Habermas]. It would seem that a purely language-analytic, propositional-theoretic account of the sensory resources of religious life cannot do justice to the sensuous, experimental and emotional dimension of religious life that are so important for religious expression and articulation. (Harrington 2007b: 552)

Notwithstanding, there are a few elements in Habermas's recent article that point in the opposite direction. Contra Harrington, my reading suggests that he associates religion with reason's striving for wholeness and the unconditioned. Further, although Habermas does not deal thoroughly with 'the faith by which we believe' he is obviously not completely blind to it either. When Habermas discusses the Holocaust, Benjamin, Horkheimer, and Adorno, he writes:

[T] he unbelieving sons and daughters of modernity seem to believe that they owe more to one another, and need more for themselves, than what is accessible to them, in translation, of religious tradition - as if the semantic potential of the latter was still not exhausted. (Habermas 2003: 111)

This passage suggests that what is yet accessible to these unbelievers is not sufficient. Habermas writes this after saying that 'The lost hope for resurrection is keenly felt as a void', presumably because of the 'irreversibility of past sufferings' (Habermas 2003: 110f). This means that unbelievers feel a void, or that they face some kind of problem. Although Habermas says that this problem remains unsolved at present, he may be understood as suggesting that we have the resources for solving it. Now Kant believes his critical philosophy had the resources when it included the belief in realising the highest good (and its conditions of possibility, God and immortality). Habermas does not want to goes as far as Kant at this point. His position is that whereas philosophy is concerned with the quest for truth and the tribunal of justificatory discourse, religion offers consolation in the light of suffering, defeat and a misspent life (cf. Habermas 2002: 162). In saying this, Habermas appears to align philosophy with reason-giving, thereby overlooking the dialectic where reason strives for the unconditioned - something which has devastating consequences for religiousness. Commenting on reflections from a damaged life (and criticizing M. Theunissen), Habermas 
writes: 'Philosophical discourses can be recognized by the fact that they stop short of the rhetoric of fate and promised salvation' (Habermas 2002: 126). He further insists that a philosophy that 'wants to offer consolation [trösten will] is not philosophy anymore' (Habermas quoted in Trautsch 2004: 184f). At this point, Habermas is clearly at odds with Kant (cf. AA 6: 171; 27: 319).

When asked by the theologian J.B. Metz if his communication theory heals all wounds, Habermas answered negatively (Trautsch 2004: 184n). Indeed, it is clear that Habermas's theory neither can nor wants to solve all problems that religion has contended to solve. Habermas has no problem recognizing this. Nevertheless, this leaves a cluster of problems. Habermas himself mentions salvation and consolidation in the face of the contingencies of life, including loneliness, guilt, illness, and death, saying that we have to live with these contingencies, principally without consolidation (prinzipiell trostlos) (see Trautsch 2004: 184). It seems that Habermas ends with a conclusion that is more Kierkegaardian than Kantian: whereas Kant wanted to use moral faith to fill our existential need for the highest good, Kierkegaard insists that philosophy cannot solve our existential and ethical problems. This could mean, however, that Habermas runs the risk of leaving some of the most important problems to private faith - something which seems like a high price to pay.

\section{Acknowledgements}

The author wishes to thank Bjørn K. Myskja and Lars Johan Materstvedt. Thanks are also due to one of the referees for very useful comments on the dialectic of reason in Kant and Habermas as well as for a comment on religious and aesthetic experience contesting the narrow analysis of the relation between validity and meaning in universal pragmatics. 


\section{Notes}

1 Although the most (in)famous example of faith relying on private criteria is Abraham in Fear and Trembling, it is not clear that humans can be in the same situation as Abraham since Fear and Trembling presupposes that Abraham is infallible and without guilt and $\sin$ (Fremstedal 2006a; 2008). Nevertheless, Kierkegaard elsewhere seems to assume that revealed faith relies on private criteria - the most important example of this probably being the analysis of the condition of faith in Fragments, understood as an analysis of conditions of possibility of revealed faith. Discussing the condition of faith, Michelle Kosch highlights some rather disturbing consequences from Kierkegaard's (Climacus's) quasi-transcendental analysis: «'TT]here could in principle be no mechanism through which one could pick out one true revealed religion from a set of pretenders to this position (since to seem to be a pretender is already to seem to have come accompanied by such a condition) [...] Kierkegaard appears to [think], that there are also no empirical criteria for determining what is a revelation and what is an ordinary historical event. [...] It seems correct, then, to say that the experience that makes belief [in the incarnation] possible is a private one' (Kosch 2006: 180, 183, 199n, respectively). It should be noted that Kierkegaard presupposes that Christianity is the true and universal religion, thereby tending to deny that any real pretenders exist.

2 What lies in the background here is (among other things) Habermas's critique of the philosophical defence of Kierkegaardian religiousness that we find in the work of Michael Theunissen (cf. Habermas 2002: 120-122). Rothberg (1986: 235f, 222f, 237) argues that in The Theory of Communicative Action Habermas does not seem to take adequate stock of the level of reflexivity reached in many contemplative religious traditions. Thus, Rothberg argues that the many religious traditions are not as dogmatic and unable to make problematic claims as Habermas claims.

3 Examples of commentators who claim that historical faith plays a crucial role in Kant are Palmquist and Firestone 2006. A somewhat more balanced account that still argues that historical faith has a role to play in Kant's theory can be found in Marina 1997.

4 Kant offers the following definition: 'Religion is (subjectively considered) the recognition of all our duties as divine commands' (AA 6: 153, cf. 106, AA 27: 713; AA 7: 36; AA 9: 494). This does not imply a theoretical knowledge of divine commands, but rather that religion is the moral disposition where duties are seen as divine commands (AA 6: 105). If we regard the Moral Law subjectively as something we are subjected to, it may be considered a divine command (cf. AA 6: 156). Note that we have to infer from the good to the divine, to infer the other way around would be idolatrous (cf. KdrV A818f/B846f; AA 6: 154, 185; AA 27: 262; AA 9: 450f). Kant may be seen as representing a special variant of divine command ethics insofar as (1) moral obligations are authored by God (and not merely by us and other possible rational beings), and (2) God is lawgiver. The latter (2) only means that God connects the Law with compulsion (Zwang) (AA 19: 300; AA 29: 634f), i.e. that He attaches sanctions to breaking the Law (Byrne 2007: 132). This can be read as saying that when we break the Moral Law, we should expect God to use sanctions or to punish us (Byrne 2007: 132). The latter does not mean that God is the author (Urheber) of the law (AA 9: 494). Kant says: 'Religion is the law in us, in so far as it receives emphasis from a lawgiver and judge above us; it is morals applied to the knowledge of God' (AA 9: 494). Clearly, Kant means that God judges on the basis of a law which is already given (cf. 1). 


\section{Literature}

Byrne, P. (2007) Kant on God. Aldershot: Ashgate.

Evans, C.S. (1999) Kierkegaard's Fragments and Postscript. The religious philosophy of Johannes Climacus. New York: Humanity Books.

Evans, C.S. (2006a) Kierkegaard's ethics of love. Divine commands \& moral obligations. Oxford: Oxford University Press.

Evans, C.S. (2006b) Kierkegaard on faith and the self. Waco, Texas: Baylor University Press.

Fremstedal, R. (2006a) Forfekter Kierkegaard fundamentalisme i Frygt og Boven? Norsk teologisk tidsskrift, 106, pp. 84-104.

Fremstedal, R. (2006b) Wittgenstein som religionsfilosof - og spesielt forholdet til Kierkegaard og kristendommen i Denkbewegungen. Norsk filosofisk tidsskrift, 41, pp. 213-225.

Fremstedal, R. (2008) Universalisme, fundamentalisme og Abraham i Frygt og Boven - et svar til Mjaaland. Norsk teologisk tidsskrift, 108, pp. 159-180.

Habermas, J. (1988) Nachmetaphysisches Denken. Frankfurt/M: Suhrkamp Verlag.

Habermas, J. (2001) Faith and knowledge - An opening. Available at http:// www.nettime.org/Lists-Archives/nettime-1-0111/msg00 100.html (Accessed 29 November 2008).

Habermas, J. (2002) Religion and rationality. Cambridge: Polity.

Habermas, J. (2003) The future of human nature. Cambridge: Polity.

Habermas, J. (2005) Zwischen Naturalismus und Religion. Frankfurt/M: Suhrkamp Verlag.

Habermas, J. (2006) Religion in the public sphere. European Journal of Philosophy, 14 (1), pp. 1-25.

Hare, J.E. (2002) The moral gap. Kantian ethics, human limits, and God's assistance. Oxford: Clarendon Press/Oxford University Press.

Harrington, A. (2007a) Habermas's theological turn? Journal for the Theory of Social Behaviour, 37(1), pp. 45-61

Harrington, A. (2007b) Habermas and 'post-secular society'. European Journal of Social Theory, 10 (4), pp. 543-560.

Knappe, U. (2004) Theory and practice in Kant and Kierkegaard. Berlin: de Gruyter. Kosch, M. (2006) Freedom and reason in Kant, Schelling, and Kierkegaard. Oxford: Oxford University Press.

Kulenkampff, J. (1978) Kants Logik des ästhetischen Urteils. Frankfurt/M: Klostermann.

Louden, R.B. (2002) Kant's impure ethics. Oxford: Oxford University Press.

Lübcke, P. (2006) Kierkegaard's concept of revelation. In Theologie zwischen Pragmatismus und Existenzdenken. Festschrift für Herman Deuser zum 60. Geburtstag, eds. G. Linde, R. Purkarthofer, H. Schulz \& P. Steinacker, pp. 405-414. Marburg: N.G. Elwert Verlag.

Marina, J. (1997) Kant on grace: A reply to his critics. Religious Studies, 33, pp. 379400.

Myskja, B.K. (2008) Rationality and religion in the public debate on embryo stem cell research and prenatal diagnostics. Medicine, Health Care and Philosophy. Available at http://www.springerlink.com/content/f3431p5m11 446u02/ $? \mathrm{p}=4 \mathrm{a} 1 \mathrm{cafc68bb} 943 \mathrm{e} 297 \mathrm{e} 6 \mathrm{~b} 111$ ead85cd0\&pi=0 (Accessed 16 December 2008). 
O’Neill, O. (1997) Kant on reason and religion. In The Tanner lectures on human values. Originally: Salt Lake City, Utah: University of Utah Press. Previously available at http://www.tannerlectures.utah.edu/lectures/oneill97.pdf

Palmquist, S. (1992) Does Kant reduce religion to morality? Kant-Studien, 83, pp. $129-148$.

Palmquist, S. \& Firestone, C.L. (eds.) (2006) Kant and the new philosophy of religion. Indianapolis: Indiana University Press.

Rothberg, D.J. (1986) Rationality and religion in Habermas's recent work: Some remarks on the relation between critical theory and the phenomenology of religion. Philosophy \& Social Criticism, 11, pp. 221-243.

Schmidt, T.M. (2005) The discourse of religion in post-secular society. Available at http://www.holbergprisen.no/images/materiell/ 2005_symposium_habermas.pdf (Accessed 27 February 2009), pp. 79-88.

Skirbekk, G. (2005) The critical ambiguous idea of a 'modernization of (religious) consciousness'. Available at http://www.holbergprisen.no/images/materiell/ 2005_symposium_habermas.pdf (Accessed 27 February 2009), pp. 26-29.

Trautsch, A. (2004) Glauben und Wissen. Philosophische Jahrbuch, 111, pp. 180198.

Wood, A.W. (1970) Kant's moral religion. Ithaca: Cornell University Press.

Wood, A.W. (2002) Kant's deism. In Unsettling obligations, ed. A.W. Wood, pp. 89106. Stanford: California, CSLI Publications.

\section{Primary sources}

AA = Kant, I. (1902ff.) Akademieausgabe, Gesammelten Schriften. Berlin: de Gruyter.

KdrV = Kant, I. (1990) Kritik der reinen Vernunft. I refer to the pages in the A and B editions, as found in Kant, I. (1990) Kritik der reinen Vernunft. Hamburg: Meiner.

Pap. = Kierkegaard, S. (1968-1978) Søren Kierkegaards Papirer. Copenhagen: Gyldendal.

SKS = Kierkegaard, S. (1997ff) Søren Kierkegaards Skrifter. Copenhagen: Gad. Users of the 1st or 2nd edition of Samlede voerker may wish to use the concordance list at http://www.sk.ku.dk/konkord (accessed 12 March 2009).

SV = Kierkegaard, S. (1994) Samlede vorker. Copenhagen: Gyldendal. 